\title{
Chemical Properties and Shelf Life of Banana (Musa sapientum L.) as Influenced by Different Postharvest Treatments
}

\author{
S. A. Zomo ${ }^{1}$, S. M. Ismail ${ }^{2}$, M. Shah Jahan ${ }^{3}$, K. Kabir ${ }^{3}$ and M. H. Kabir ${ }^{3}$ \\ ${ }^{1}$ Department of Agriculture Extension (DAE), Dhaka, Bangladesh; ${ }^{2}$ Bangladesh Sugar and Food \\ Industries Corporation, Dhaka, Bangladesh; ${ }^{3}$ Department of Horticulture, Faculty of Agriculture, \\ Sher-e-Bangla Agricultural University, Dhaka-1207, Bangladesh
}

*Corresponding author and Email: shahjahansau@gmail.com

Received: 19 May 2014

Accepted: 13 December 2014

\begin{abstract}
An experiment was conducted to evaluate the changes in the chemical properties of banana fruits and their shelf life as influenced by different postharvest treatments. There were two varieties viz. Amritasagar $\left(\mathrm{V}_{\mathrm{I}}\right)$ and Sabri $\left(\mathrm{V}_{2}\right)$ and seven storage treatments viz.: control (open space, $\left.30 \pm 2^{\circ} \mathrm{C}\right)\left(\mathrm{T}_{0}\right)$; perforated polyethylene, $30 \pm 2^{\circ} \mathrm{C}\left(\mathrm{T}_{1}\right)$; non-perforated polyethylene, $30 \pm 2^{\circ} \mathrm{C}\left(\mathrm{T}_{2}\right)$; benzyl adenine $(\mathrm{BA}$ $\left.30 \mathrm{ppm}, 30 \pm 2^{\circ} \mathrm{C}\right)\left(\mathrm{T}_{3}\right)$; gibberellic acid $\left(\mathrm{GA}_{3} 150 \mathrm{ppm}, 30 \pm 2^{\circ} \mathrm{C}\right)\left(\mathrm{T}_{4}\right)$; benzyl adenine (BA $30 \mathrm{ppm}$, $\left.15^{\circ} \mathrm{C}\right)\left(\mathrm{T}_{5}\right)$ and gibberellic acid $\left(\mathrm{GA}_{3} 150 \mathrm{ppm}, 15^{\circ} \mathrm{C}\right)\left(\mathrm{T}_{6}\right)$. A factorial experiment was laid out in the Completely Randomized Design (CRD) with three replications. Data were recorded on titratable acid content, total sugar content, reducing sugar content, non-reducing sugar content, total soluble solids and pulp pH. Among the chemical parameters, total soluble solids (TSS) and $\mathrm{pH}$ of pulp increased while titratable acidity decreased during storage in all the treated and untreated banana fruits. Among the treatments gibberellic acid $\left(\mathrm{GA}_{3} 150 \mathrm{ppm}, 15^{\circ} \mathrm{C}\right)$ treatment exhibited the best storage performance. The treatment combinations of Sabri with gibberellic acid $\left(\mathrm{GA}_{3} 150 \mathrm{ppm}, 15^{\circ} \mathrm{C}\right)$ showed the longest shelf life (16.25 days), whereas the lowest shelf life was in Amritasagar with control (open space, $30 \pm 2^{\circ} \mathrm{C}$ ) treatment combination (6.78 days).
\end{abstract}

Keywords: Banana, chemical properties, shelf life, storage environment

\section{Introduction}

Banana (Musa sapientum L.) is one of the important tropical fruits with a global annual production of about 145.4 million metric tones of which Asia contributes 69 million tonnes (FAO, 2011). It is a good source of income to the farmers in their respective growing regions (Bridge, 2000; Akinyemi et al., 2010). Bangladesh produces 4.22 million tonnes of fruits annually from 0.15 million hectares of which banana ranks first in respect of area (0.06 million hectare) and second in production $(0.82$ million tones) (BBS, 2010). The minimum dietary requirement of fruits per day per person in Bangladesh is $115 \mathrm{~g}$, whereas, availability is only 30- 35 g (Siddiqui et al., 1995). Sometimes this per capita availability of fruits decreased further due to high level of postharvest losses (Mondal et al., 1995).

Fruit growth and development involve many changes in its morphology, anatomy, physiology and biochemistry (El-Otmani et al., 1987). When a fruit matures, the changes occur in rind texture, juice composition and taste (Chahidi et al., 
2008). pH and mineral composition may also influence the catalytic activity of cell wall enzymes and can have a profound effect on anthocyanin stability and color expression (Huber and O'Donoghue, 1993; Almeida and Huber, 1999; Holcroft and Kader, 1999). A total soluable solid (TSS) is an important quality attribute for many fresh fruits during ripening ( $\mathrm{Lu}, 2004)$. It was reported that fruit $\mathrm{pH}$ changes was 3.0 in orange juices (Kelebek et al., 2008), 4.2 to 4.4 during storage in peaches (Zhang et al., 2008) and 3.0 to 3.5 in citrus fruits (Chahidi et al., 2008) during storage. During fruit ripening and softening process, starch is broken down to the simple soluble sugars and also the amount of soluble pectin will increase, leading to fruit softening (Afshar et al., 2010).

Kulkarni and Aradhya (2005) suggested that a slow decrease in acidity, concomitant with increased TSS and total sugar content, is an intrinsic process during the ripening of fruits to impart the flavor. The effects of the chemical dip, calcium chloride, ascorbic acid and modified atmosphere storage improved the quality and shelf life of banana (Reis et al., 2004). The objectives of the present study were to find out the chemical and bio-chemical changes of two banana varieties in response to different postharvest treatments and identify the suitable storage treatments to maintain the quality and to increase shelf life of banana fruits.

\section{Materials and Methods}

The experiment was conducted at the laboratories of the Department of Horticulture and Department of Biochemistry, Bangladesh Agricultural University, Mymensingh, during September, 2004 to December, 2004. The study consisted of two factors; factor A: varieties, $V_{1}$ : Amritasagar and $\mathrm{V}_{2}$ : Sabri; factor $\mathrm{B}$ : different postharvest treatments, $\mathrm{T}_{0}$ : control (open space, $\left.30 \pm 2^{\circ} \mathrm{C}\right), \mathrm{T}_{1}$ : fruits were kept at $30 \pm 2^{\circ} \mathrm{C}$ in perforated polyethylene bag, $\mathrm{T}_{2}$ : fruits were kept at $30 \pm 2^{\circ} \mathrm{C}$ in non perforated polyethylene bag, $\mathrm{T}_{3}$ : fruits were treated with benzyl adenine (BA $30 \mathrm{ppm}, 30 \pm 2^{\circ} \mathrm{C}$ ), $\mathrm{T}_{4}$ : fruits were treated with gibberellic acid $\left(\mathrm{GA}_{3} 150 \mathrm{ppm}, 30 \pm 2^{\circ} \mathrm{C}\right), \mathrm{T}_{5}$ : fruits were treated with benzyl adenine (BA 30 ppm, $\left.15^{\circ} \mathrm{C}\right), \quad \mathrm{T}_{6}$ : fruits were treated with gibberellic acid $\left(\mathrm{GA}_{3} 150 \mathrm{ppm}, 15^{\circ} \mathrm{C}\right)$. The experiment was laid out in a Completely Randomized Design (CRD) with three replications. The post harvest treatments were randomly assigned to the selected banana fruits. After the application of treatments, some of the fruits were kept on a brown paper previously placed on the laboratory floor at room temperature $\left(30 \pm 2^{\circ} \mathrm{C}\right)$ and others were kept in a refrigerator. Each treatment comprised of eight banana fingers.

One banana finger of each treatment was collected at 3, 6, 9 and 12 days of storage for chemical analysis. Titratable acid content was determined according to Ranganna (1979). Total sugar content was determined colorimetrically using the anthrone method (Jayaraman, 1981). Reducing sugar content was determined using the dinitrosalicylic acid method (Miller, 1972). Non-reducing sugar content was calculated using the following formula: \% Non-reducing sugar = Total sugar - Reducing sugar. Total soluble solids (TSS) content of pulp was estimated using Abbe's refractometer. A drop of banana juice squeezed from the fruit pulp was placed on the prism of the refractometer. Percent TSS was obtained from the direct reading of the instrument.

The collected data were statistically analyzed following $F$ variance tests. The difference between the pair of means was compared using LSD (Gomez and Gomez, 1984).

\section{Results and Discussion}

\subsection{Titratable acidity}

Of the two varieties, $\mathrm{V}_{2}$ (Sabri) contained higher titratable acidity $(0.51 \%)$ than $\mathrm{V}_{1}$ (Amritasagar) $(0.49 \%)$ at the $9^{\text {th }}$ day of storage. Titratable acidity decreased gradually with the passage of the storage period in all treatments (Fig. 1). The maximum titratable acidity $(0.63 \%)$ was found at 
the $9^{\text {th }}$ day of storage in $\mathrm{T}_{6}$ while the minimum $(0.41 \%)$ was noticed in $\mathrm{T}_{0}$ (Fig. 2). The decrease in titratable acidity during the storage may be attributed to the utilization of organic acids in various bio-degradable reactions. The highest titratable acidity $(0.65 \%)$ was recorded in $\mathrm{V}_{2} \mathrm{~T}_{6}$ but the lowest $(0.40 \%)$ was observed in $\mathrm{V}_{1} \mathrm{~T}_{0}$ at the $9^{\text {th }}$ day of storage (Table 1). Pinaki et al. (1997) conducted an experiment with mature and fully developed banana fruits of uniform size dipped in $\mathrm{GA}_{3} @ 150$ ppm and found that $\mathrm{GA}_{3}$ retained higher titratable acidity and slowed the decrease in ascorbic acid content of fruits during their storage.

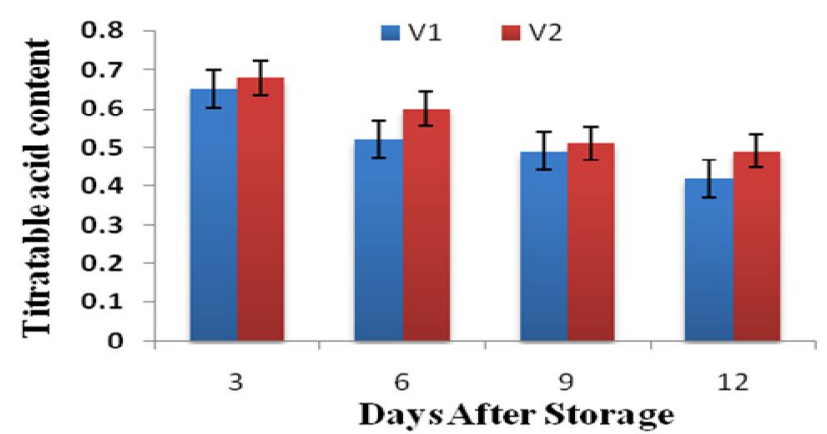

Figure 1. Effect of varieties on the titratable acid content of banana (vertical bars represent SE of the three replications)

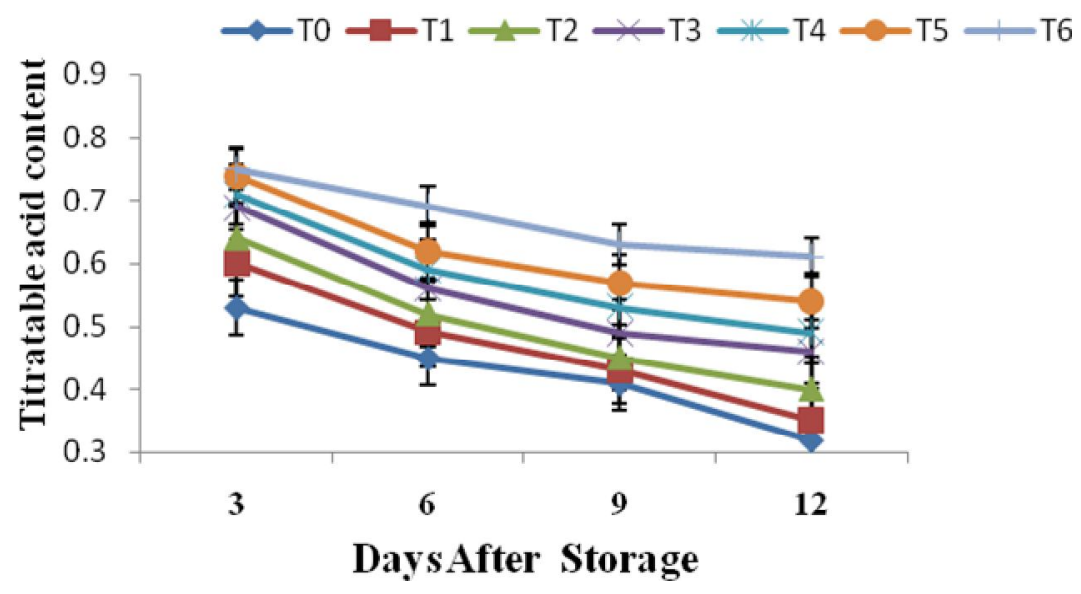

Figure 2. Effect of postharvest treatments on the titratable acid content of banana (vertical bars represent SE of the three replications)

$\mathrm{V}_{1}$ : Amritasagar, $\mathrm{V}_{2}$ : Sabri, $\mathrm{T}_{0}=$ control (open space, $30 \pm 2^{\circ} \mathrm{C}$ ), $\mathrm{T}_{1}=$ (perforated polyethylene, $30 \pm 2^{\circ} \mathrm{C}$ ), $\mathrm{T}_{2}=$ (non-perforated polyethylene, $30 \pm 2^{\circ} \mathrm{C}$ ), $\mathrm{T}_{3}=$ benzyl adenine $\left(\mathrm{BA} 30 \mathrm{ppm}, 30 \pm 2^{\circ} \mathrm{C}\right.$ ), $\mathrm{T}_{4}=$ gibberellic acid $\left(\mathrm{GA}_{3} 150 \mathrm{ppm}, 30 \pm 2^{\circ} \mathrm{C}\right), \mathrm{T}_{5}=$ benzyl adenine $\left(\mathrm{BA} 30 \mathrm{ppm}, 15^{\circ} \mathrm{C}\right) \mathrm{T}_{6}=$ gibberellic acid $\left(\mathrm{GA}_{3} 150 \mathrm{ppm}, 15^{\circ} \mathrm{C}\right), \mathrm{SE}=$ standard error 


\subsection{Total sugar contents}

At the $9^{\text {th }}$ day of storage, the highest total sugar contents $(21 \%)$ were recorded in $\mathrm{V}_{1}$ while the lowest $\left(20.13 \%\right.$ ) was observed in $\mathrm{V}_{2}$ (Fig. 3). The maximum sugar content $(25.74 \%)$ was recorded in control whereas the minimum (15.31\%) was found in $\mathrm{T}_{6}$ (Fig. 4). The most striking chemical changes occured during the postharvest ripening of banana fruits were hydrolysis of starch and accumulation of sugars (Patil and Magar, 1976). Considering the interaction effects of banana varieties and different postharvest treatments, significant variations where found on total sugar contents in fruit pulp at the $9^{\text {th }}$ and the $12^{\text {th }}$ days of storage. However, the highest total sugar content $(26.9$ $\%$ ) was recorded in $\mathrm{V}_{1} \mathrm{~T}_{0}$ while the minimum $(15 \%)$ was in $\mathrm{V}_{2} \mathrm{~T}_{6}$ at $9^{\text {th }}$ day of storage (Table $1)$.

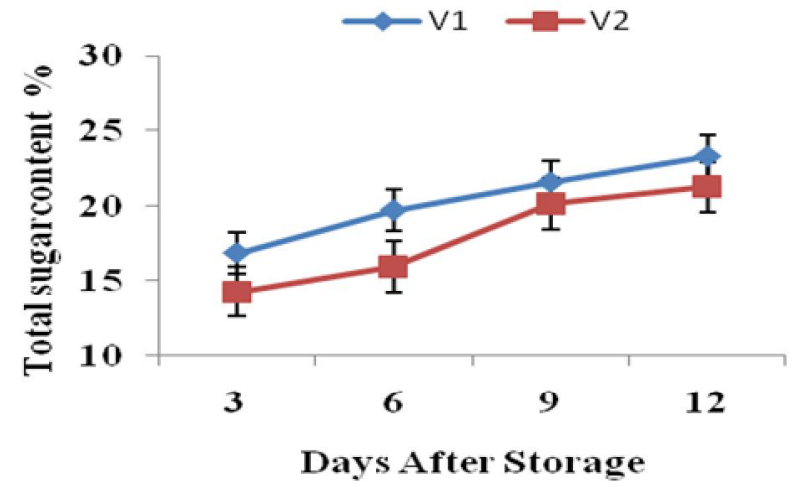

Figure 3. Effect of varieties on the total sugar content (\%) of banana (vertical bars represent SE of the three replications)

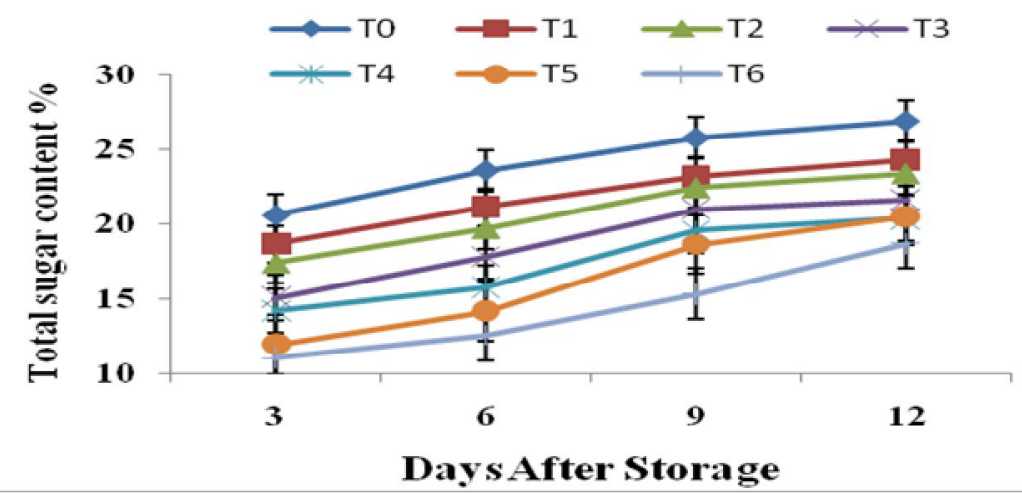

Figure 4. Effect of postharvest treatments on the total sugar content (\%) of banana (vertical bars represent SE of the three replications)

$\mathrm{V}_{1}$ : Amritasagar, $\mathrm{V}_{2}$ : Sabri, $\mathrm{T}_{0}=$ control (open space, $30 \pm 2^{\circ} \mathrm{C}$ ), $\mathrm{T}_{1}=$ (perforated polyethylene, $30 \pm 2^{\circ} \mathrm{C}$ ), $\mathrm{T}_{2}=$ (non-perforated polyethylene, $30 \pm 2^{\circ} \mathrm{C}$ ), $\mathrm{T}_{3}=$ benzyl adenine $\left(\mathrm{BA} 30 \mathrm{ppm}, 30 \pm 2^{\circ} \mathrm{C}\right.$ ), $\mathrm{T}_{4}=$ gibberellic acid $\left(\mathrm{GA}_{3} 150 \mathrm{ppm}, 30 \pm 2^{\circ} \mathrm{C}\right), \mathrm{T}_{5}=$ benzyl adenine $\left(\mathrm{BA} 30 \mathrm{ppm}, 15^{\circ} \mathrm{C}\right) \mathrm{T}_{6}=$ gibberellic acid $\left(\mathrm{GA}_{3} 150 \mathrm{ppm}, 15^{\circ} \mathrm{C}\right), \mathrm{SE}=$ standard error 


\subsection{Reducing sugar content}

Highly significant variations were observed in the reducing sugar content between the two varieties at different days of storage. The maximum reducing sugar content $(11.41 \%)$ was recorded in $\mathrm{V}_{1}$ and the minimum $(10.59 \%)$ in $\mathrm{V}_{2}$ at the $9^{\text {th }}$ day of storage (Fig. 5). The highest reducing sugar content $(14.77 \%)$ was found in $\mathrm{T}_{0}$ but the lowest $(8.79 \%)$ was in $\mathrm{T}_{6}$ at the $9^{\text {th }}$ day of storage (Fig. 6). The increase in reducing sugar may be attributed to enzymatic conversion of starch to reducing sugar (Islam, 1998). The higher amount of reducing sugar content (15.85) was recorded in $\mathrm{V}_{1} \mathrm{~T}_{0}$ while the smaller amount $(8.23 \%)$ was in $\mathrm{V}_{2} \mathrm{~T}_{6}$ (Table 1). Bhadra and Sen (1999) mentioned that the total sugar and reducing sugar contents increased with in the progress of the storage period.

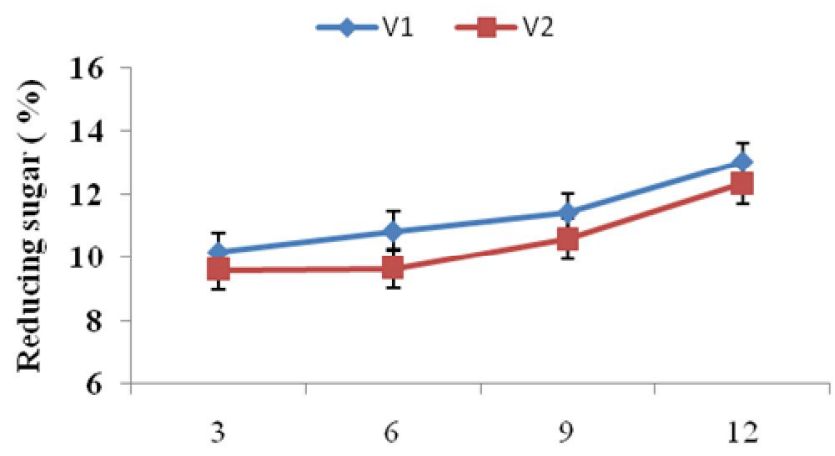

Days After Storage

Figure 5. Effect of varieties on the reducing sugar content (\%) of banana (vertical bars represent SE of the three replications)

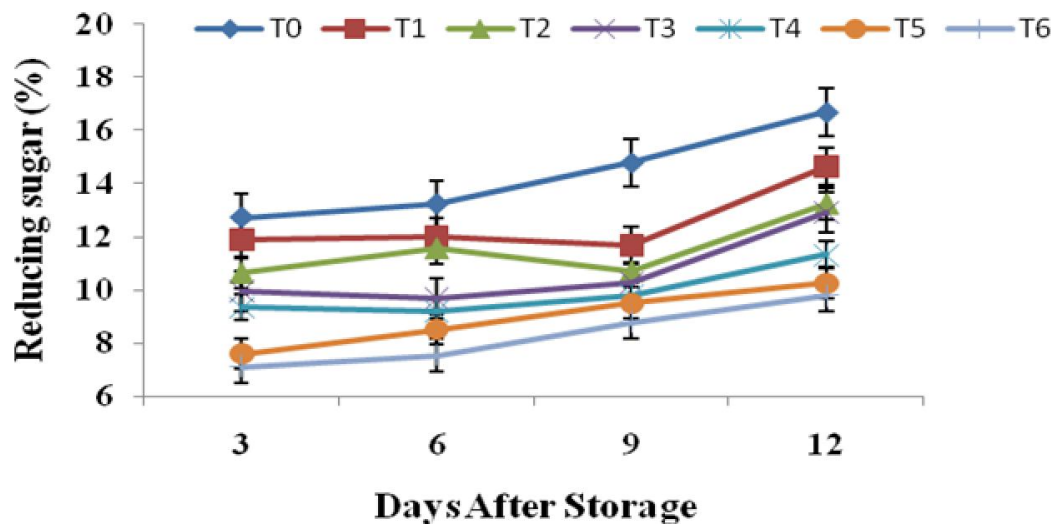

Figure 6. Effect of postharvest treatments on the reducing sugar content (\%) of banana (vertical bars represent $\mathrm{SE}$ of the three replications)

$\mathrm{V}_{1}$ : Amritasagar, $\mathrm{V}_{2}$ : Sabri, $\mathrm{T}_{0}=$ control (open space, $30 \pm 2^{\circ} \mathrm{C}$ ), $\mathrm{T}_{1}=$ (perforated polyethylene, $30 \pm 2^{\circ} \mathrm{C}$ ), $\mathrm{T}_{2}=$ (non-perforated polyethylene, $30 \pm 2^{\circ} \mathrm{C}$ ), $\mathrm{T}_{3}=$ benzyl adenine $\left(\mathrm{BA} 30 \mathrm{ppm}, 30 \pm 2^{\circ} \mathrm{C}\right.$ ), $\mathrm{T}_{4}=$ gibberellic acid $\left(\mathrm{GA}_{3} 150 \mathrm{ppm}, 30 \pm 2^{\circ} \mathrm{C}\right), \mathrm{T}_{5}=$ benzyl adenine $\left(\mathrm{BA} 30 \mathrm{ppm}, 15^{\circ} \mathrm{C}\right) \mathrm{T}_{6}=$ gibberellic acid $\left(\mathrm{GA}_{3} 150 \mathrm{ppm}, 15^{\circ} \mathrm{C}\right), \mathrm{SE}=$ standard error 


\subsection{Non-reducing sugar content}

Higher non-reducing sugar content (7.51) was observed in $\mathrm{V}_{1}$ while $\mathrm{V}_{2}$ contained the lower amount of non-reducing sugar $(6.91 \%)$ at the $9^{\text {th }}$ day of storage (Fig. 7). At the $9^{\text {th }}$ day of storage, the maximum non-reducing sugar content $(9.46 \%)$ was obtained from $\mathrm{T}_{0}$ and the least value $5.64 \%$ in from $\mathrm{T}_{6}$ (Fig. 8). At the $9^{\text {th }}$ day of storage, the highest (10.05) non-reducing sugar content was observed in $\mathrm{V}_{1} \mathrm{~T}_{0}$ and the lowest
(5.02 \%) was in $\mathrm{V}_{2} \mathrm{~T}_{6}$ (Table 1). The nonreducing sugar content increased rapidly from the $3^{\text {rd }}$ to the $9^{\text {th }}$ day of storage and then changed slowly after the $9^{\text {th }}$ day of storage. Rapidly increased non-reducing sugar was probably due to breakdown of starch into non-reducing sugar and then that non-reducing sugar was converted into reducing sugar resulting slowly increase in non-reducing sugar. In mango, Rangavalli et al. (1993) found a gradual increase in the nonreducing sugar content during its storage.

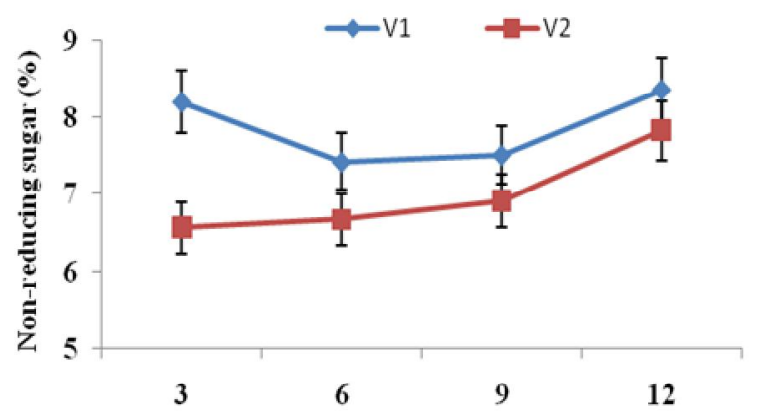

Days After Storage

Figure 7. Effect of varieties on the non-reducing sugar content (\%) of banana (vertical bars represent SE of the three replications)

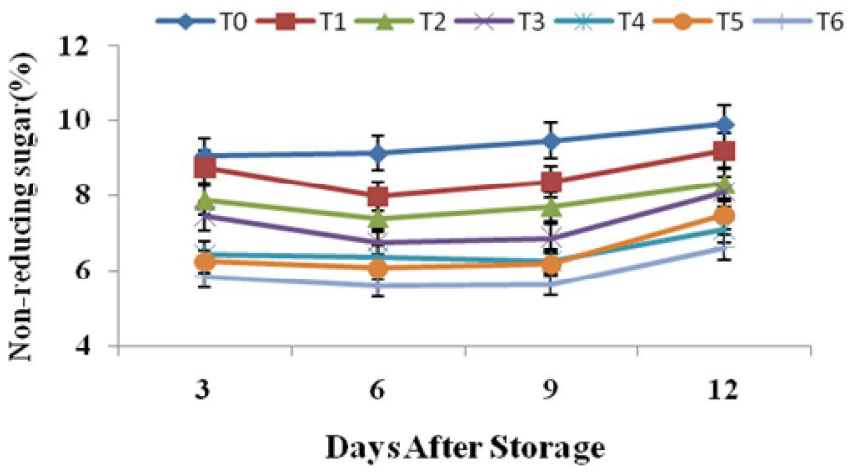

Figure 8. Effect of postharvest treatments on the non-reducing sugar content (\%) of banana (vertical bars represent SE of the three replications)

$\mathrm{V}_{1}$ : Amritasagar, $\mathrm{V}_{2}$ : Sabri, $\mathrm{T}_{0}=$ control (open space, $30 \pm 2^{\circ} \mathrm{C}$ ), $\mathrm{T}_{1}=$ (perforated polyethylene, $30 \pm 2^{\circ} \mathrm{C}$ ), $\mathrm{T}_{2}=$ (non-perforated polyethylene, $30 \pm 2^{\circ} \mathrm{C}$ ), $\mathrm{T}_{3}=$ benzyl adenine $\left(\mathrm{BA} 30 \mathrm{ppm}, 30 \pm 2^{\circ} \mathrm{C}\right.$ ), $\mathrm{T}_{4}=$ gibberellic acid $\left(\mathrm{GA}_{3} 150 \mathrm{ppm}, 30 \pm 2^{\circ} \mathrm{C}\right), \mathrm{T}_{5}=$ benzyl adenine $\left(\mathrm{BA} 30 \mathrm{ppm}, 15^{\circ} \mathrm{C}\right) \mathrm{T}_{6}=$ gibberellic acid $\left(\mathrm{GA}_{3} 150 \mathrm{ppm}, 15^{\circ} \mathrm{C}\right), \mathrm{SE}=$ standard error 
Table 1. Combined effects of varieties and postharvest treatments on titratable acidity, total sugar, reducing sugar and non-reducing sugar contents of banana

\begin{tabular}{|c|c|c|c|c|c|c|c|c|c|c|c|c|c|c|c|c|}
\hline \multirow{2}{*}{$\begin{array}{l}\text { Variety } \times \\
\text { Treatments }\end{array}$} & \multicolumn{4}{|c|}{ Titratable acidity at DAS } & \multicolumn{4}{|c|}{$\%$ total sugar at DAS } & \multicolumn{4}{|c|}{$\%$ Reducing sugar at DAS } & \multicolumn{4}{|c|}{$\%$ Non-reducing sugar at DAS } \\
\hline & 3 & 6 & 9 & 12 & 3 & 6 & 9 & 12 & 3 & 6 & 9 & 12 & 3 & 6 & 9 & 12 \\
\hline $\mathrm{V}_{1} \mathrm{~T}_{0}$ & 0.52 & 0.42 & 0.40 & 0.29 & 21.49 & 25.53 & 26.9 & 27.8 & 13.87 & 14.21 & 15.85 & 17.43 & 9.61 & 9.48 & 10.05 & 10.73 \\
\hline $\mathrm{V}_{1} \mathrm{~T}_{1}$ & 0.59 & 0.45 & 0.42 & 0.32 & 20.01 & 23.47 & 24.45 & 26.45 & 12.60 & 12.87 & 12.05 & 15.61 & 9.62 & 8.49 & 8.66 & 9.51 \\
\hline $\mathrm{V}_{1} \mathrm{~T}_{2}$ & 0.63 & 0.47 & 0.45 & 0.36 & 18.69 & 21.12 & 23.95 & 25.72 & 10.97 & 11.8 & 10.64 & 13.21 & 8.66 & 8.15 & 8.27 & 8.84 \\
\hline $\mathrm{V}_{1} \mathrm{~T}_{3}$ & 0.68 & 0.51 & 0.48 & 0.43 & 16.95 & 19.59 & 21.54 & 23.09 & 9.72 & 10.19 & 10.22 & 13.40 & 8.26 & 6.73 & 6.85 & 8.02 \\
\hline $\mathrm{V}_{1} \mathrm{~T}_{4}$ & 0.68 & 0.55 & 0.53 & 0.46 & 15.69 & 17.18 & 19.96 & 20.75 & 9.49 & 9.77 & 9.54 & 11.39 & 7.07 & 6.41 & 6.36 & 7.03 \\
\hline $\mathrm{V}_{1} \mathrm{~T}_{5}$ & 0.70 & 0.59 & 0.57 & 0.51 & 13.45 & 16.4 & 18.60 & 21.21 & 7.46 & 9.19 & 9.20 & 10.37 & 6.93 & 6.39 & 6.11 & 7.51 \\
\hline $\mathrm{V}_{1} \mathrm{~T}_{6}$ & 0.73 & 0.66 & 0.61 & 0.55 & 11.67 & 14.62 & 15.62 & 18.00 & 7.12 & 7.77 & 8.34 & 9.79 & 7.25 & 6.30 & 6.26 & 6.88 \\
\hline $\mathrm{V}_{2} \mathrm{~T}_{0}$ & 0.55 & .49 & 0.43 & 0.35 & 19.74 & 21.67 & 24.57 & 25.9 & 11.55 & 12.23 & 12.70 & 15.90 & 8.52 & 8.77 & 8.87 & 9.04 \\
\hline $\mathrm{V}_{2} \mathrm{~T}_{1}$ & 0.61 & 0.53 & 0.44 & 0.38 & 17.35 & 18.87 & 22.00 & 22.22 & 11.14 & 11.08 & 11.26 & 13.67 & 7.88 & 7.45 & 8.08 & 8.88 \\
\hline $\mathrm{V}_{2} \mathrm{~T}_{2}$ & 0.65 & 0.57 & 0.45 & 0.44 & 16.05 & 18.28 & 20.88 & 21.03 & 10.30 & 11.31 & 10.78 & 13.25 & 7.08 & 6.64 & 7.10 & 7.78 \\
\hline $\mathrm{V}_{2} \mathrm{~T}_{3}$ & 0.70 & 0.61 & 0.49 & 0.50 & 13.15 & 16.03 & 20.52 & 20.23 & 10.17 & 9.16 & 10.28 & 12.40 & 6.65 & 6.79 & 6.90 & 8.16 \\
\hline $\mathrm{V}_{2} \mathrm{~T}_{4}$ & 0.73 & 0.63 & 0.54 & 0.52 & 12.67 & 14.35 & 19.22 & 20.05 & 9.19 & 8.64 & 10.07 & 11.24 & 5.84 & 6.33 & 6.15 & 7.14 \\
\hline $\mathrm{V}_{2} \mathrm{~T}_{5}$ & 0.77 & 0.65 & 0.58 & 0.57 & 10.40 & 11.91 & 18.69 & 19.92 & 7.72 & 7.85 & 9.82 & 10.13 & 5.56 & 5.75 & 6.23 & 7.44 \\
\hline $\mathrm{V}_{2} \mathrm{~T}_{6}$ & 0.78 & 0.71 & 0.65 & 0.60 & 10.42 & 10.53 & 15.00 & 19.45 & 7.11 & 7.28 & 8.23 & 8.80 & 4.40 & 4.91 & 5.02 & 6.36 \\
\hline $\operatorname{LSD}(0.01)$ & 0.02 & 0.02 & 0.02 & 0.02 & 2.31 & 2.09 & 2.26 & 0.02 & 1.23 & 1.59 & 1.25 & 1.73 & 1.26 & 1.2 & 1.22 & 1.39 \\
\hline $\operatorname{LSD}(0.05)$ & 0.02 & 0.02 & 0.02 & 0.02 & 1.71 & 1.55 & 1.62 & 0.02 & 0.91 & 1.18 & 0.93 & 1.28 & 0.93 & 0.89 & 0.09 & 1.03 \\
\hline
\end{tabular}

DAS- Days After Storage, $\mathrm{V}_{1}$ : Amritasagar, $\mathrm{V}_{2}$ : Sabri, $\mathrm{T}_{0}=$ control (open space, $30 \pm 2^{\circ} \mathrm{C}$ ), $\mathrm{T}_{1}=$ (perforated polyethylene, $30 \pm 2^{\circ} \mathrm{C}$ ), $\mathrm{T}_{2}=($ non-perforated polyethylene, $\left.30 \pm 2^{\circ} \mathrm{C}\right), \mathrm{T}_{3}=$ benzyl adenine $\left(\mathrm{BA} 30 \mathrm{ppm}, 30 \pm 2^{\circ} \mathrm{C}\right), \mathrm{T}_{4}=$ gibberellic acid $\left(\mathrm{GA}_{3} 150 \mathrm{ppm}, 30 \pm 2^{\circ} \mathrm{C}\right), \mathrm{T}_{5}=$ benzyl adenine $\left(\mathrm{BA} 30 \mathrm{ppm}, 15^{\circ} \mathrm{C}\right) \mathrm{T}_{6}=$ gibberellic acid $\left(\mathrm{GA}_{3} 150 \mathrm{ppm}, 15^{\circ} \mathrm{C}\right)$ 
Table 2. Effect of varieties on the percent total soluble solids (TSS) and pH of banana

\begin{tabular}{lcccccccc}
\hline \multirow{2}{*}{ Variety } & \multicolumn{3}{c}{ TSS $(\%)$ at DAS } & \multicolumn{5}{c}{ pH at DAS } \\
\cline { 2 - 9 } & 3 & 6 & 9 & 12 & 3 & 6 & 9 & 12 \\
\hline $\mathrm{V}_{1}$ & 18.97 & 19.71 & 24.39 & 19.55 & 3.68 & 5.91 & 6.13 & 6.28 \\
$\mathrm{~V}_{2}$ & 15.23 & 16.72 & 17.47 & 18.62 & 3.32 & 5.44 & 5.86 & 6.03 \\
\hline LSD $(0.01)$ & 0.76 & $\mathbf{0 . 7 3}$ & 0.74 & 0.76 & 0.22 & 0.39 & 0.49 & 0.55 \\
LSD (0.05) & 0.56 & 0.54 & 0.55 & 0.57 & 0.17 & 0.29 & 0.36 & 0.40 \\
\hline
\end{tabular}

$\mathrm{V}_{1}$ : Amritasagar, $\mathrm{V}_{2}$ : Sabri, DAS- Days After Storage

Table 3. Effect of postharvest treatments on percent total soluble solids (TSS) and pH of banana

\begin{tabular}{lcccccccc}
\hline \multirow{2}{*}{ Treatments } & \multicolumn{4}{c}{ TSS $(\%)$ at DAS } & \multicolumn{4}{c}{$\mathrm{pH}$ at DAS } \\
\cline { 2 - 9 } & 3 & 6 & 9 & 12 & 3 & 6 & 9 & 12 \\
\hline $\mathrm{T}_{0}$ & 24.16 & 24.54 & 26.86 & 23.99 & 4.80 & 5.94 & 6.28 & 6.81 \\
$\mathrm{~T}_{1}$ & 22.57 & 21.93 & 24.06 & 22.58 & 4.58 & 5.79 & 5.98 & 6.96 \\
$\mathrm{~T}_{2}$ & 19.96 & 20.15 & 22.34 & 21.46 & 3.90 & 5.92 & 5.87 & 6.41 \\
$\mathrm{~T}_{3}$ & 16.47 & 17.99 & 20.68 & 18.95 & 3.55 & 5.53 & 5.56 & 5.94 \\
$\mathrm{~T}_{4}$ & 14.09 & 15.69 & 18.71 & 16.98 & 2.91 & 5.88 & 5.14 & 4.60 \\
$\mathrm{~T}_{5}$ & 12.02 & 14.41 & 17.73 & 15.36 & 2.46 & 5.83 & 4.69 & 4.62 \\
$\mathrm{~T}_{6}$ & 10.44 & 12.81 & 16.12 & 14.28 & 2.29 & 4.08 & 4.46 & 4.59 \\
\hline LSD (0.01) & 1.40 & 1.37 & 1.39 & 1.37 & 0.42 & 1.04 & 0.92 & 1.02 \\
LSD (0.05) & 1.05 & 1.02 & 1.03 & 1.02 & 0.31 & 0.77 & 0.68 & 0.76 \\
\hline
\end{tabular}

Table 4. Combined effects of varieties and postharvest treatments on total soluble solids (TSS) and pH of banana

\begin{tabular}{lcccccccc}
\hline Variety $\times$ & \multicolumn{3}{c}{ TSS $(\%)$ at DAS } & \multicolumn{5}{c}{ pH at DAS } \\
\cline { 2 - 8 } Treatments & 3 & 6 & 9 & 12 & 3 & 6 & 9 & 12 \\
\hline $\mathrm{V}_{1} \mathrm{~T}_{0}$ & 25.89 & 25.12 & 28.35 & 24.98 & 4.99 & 6.60 & 6.79 & 6.82 \\
$\mathrm{~V}_{1} \mathrm{~T}_{1}$ & 24.78 & 23.67 & 25.79 & 22.28 & 4.81 & 6.35 & 6.29 & 6.54 \\
$\mathrm{~V}_{1} \mathrm{~T}_{2}$ & 22.61 & 22.31 & 24.7 & 21.62 & 4.49 & 6.54 & 6.38 & 6.01 \\
$\mathrm{~V}_{1} \mathrm{~T}_{3}$ & 19.32 & 19.45 & 24.39 & 19.54 & 3.92 & 5.37 & 6.25 & 6.55 \\
$\mathrm{~V}_{1} \mathrm{~T}_{4}$ & 16.44 & 17.71 & 23.67 & 17.45 & 2.92 & 5.80 & 5.91 & 5.41 \\
$\mathrm{~V}_{1} \mathrm{~T}_{5}$ & 13.12 & 15.71 & 22.28 & 15.81 & 2.40 & 5.64 & 5.49 & 5.79 \\
$\mathrm{~V}_{1} \mathrm{~T}_{6}$ & 10.65 & 13.98 & 21.58 & 15.20 & 2.24 & 5.05 & 4.79 & 4.34 \\
$\mathrm{~V}_{2} \mathrm{~T}_{0}$ & 22.43 & 23.96 & 25.38 & 23.00 & 4.62 & 5.29 & 6.77 & 6.30 \\
$\mathrm{~V}_{2} \mathrm{~T}_{1}$ & 20.35 & 20.20 & 22.33 & 22.88 & 4.34 & 5.22 & 5.68 & 6.39 \\
$\mathrm{~V}_{2} \mathrm{~T}_{2}$ & 17.3 & 17.98 & 19.98 & 21.31 & 3.32 & 5.30 & 5.35 & 5.81 \\
$\mathrm{~V}_{2} \mathrm{~T}_{3}$ & 13.62 & 16.52 & 16.97 & 18.37 & 3.18 & 5.69 & 4.87 & 5.33 \\
$\mathrm{~V}_{2} \mathrm{~T}_{4}$ & 11.73 & 13.67 & 13.76 & 16.51 & 2.91 & 5.96 & 4.36 & 4.79 \\
$\mathrm{~V}_{2} \mathrm{~T}_{5}$ & 10.92 & 13.10 & 13.18 & 14.92 & 2.52 & 6.02 & 4.89 & 4.45 \\
$\mathrm{~V}_{2} \mathrm{~T}_{6}$ & 10.23 & 10.67 & 11.65 & 13.35 & 2.33 & 4.07 & 4.12 & 4.12 \\
\hline LSD (0.01) & 2.45 & 2.37 & 2.41 & 2.02 & 0.72 & 1.27 & 1.29 & 1.44 \\
LSD $(0.05)$ & 1.82 & 1.76 & 1.79 & 1.49 & 0.53 & 0.94 & 0.96 & 1.07 \\
\hline
\end{tabular}




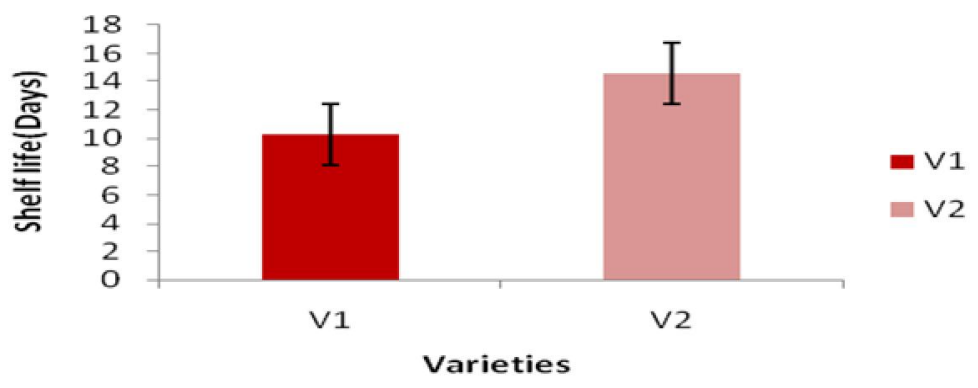

Figure 9. Effect of varieties on the shelf life of banana (vertical bars represent SE of the three replications)

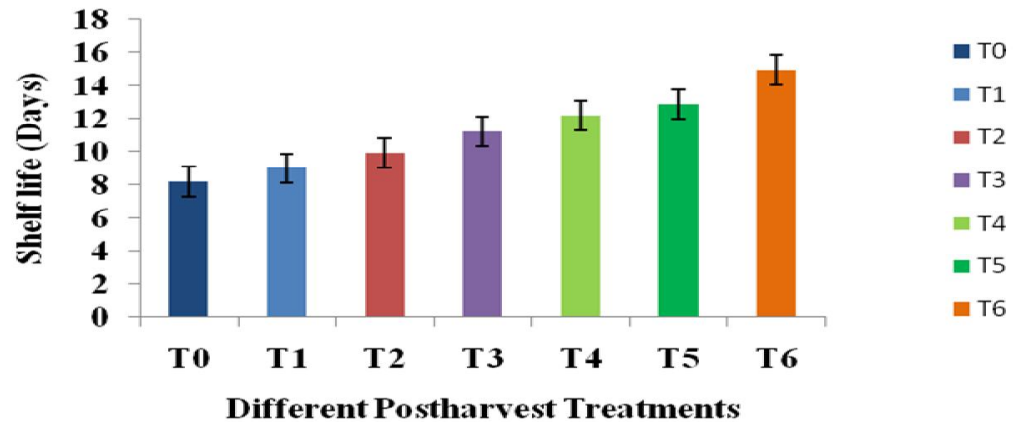

Figure 10. Effect of postharvest treatments on the shelf life of banana (vertical bars represent SE of the three replications)

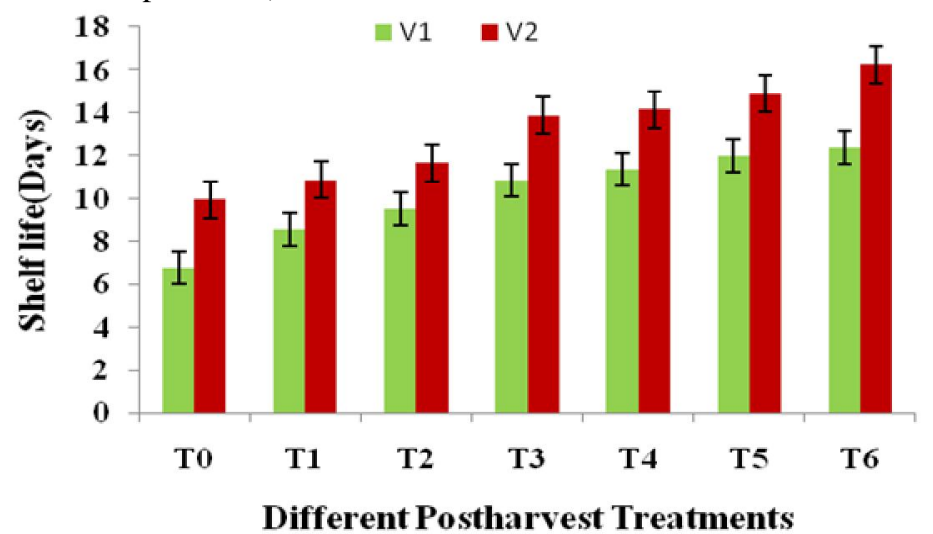

Figure 11. Combined effects of varieties and different postharvest treatment on the shelf life of Banana (vertical bars represent SE of the three replications)

$\mathrm{V}_{1}$ : Amritasagar , $\mathrm{V}_{2}$ : Sabri, $\mathrm{T}_{0}=$ control (open space, $30 \pm 2^{\circ} \mathrm{C}$ ), $\mathrm{T}_{1}=$ (perforated polyethylene, $30 \pm 2^{\circ} \mathrm{C}$ ), $\mathrm{T}_{2}=$ (non-perforated polyethylene, $30 \pm 2^{\circ} \mathrm{C}$ ), $\mathrm{T}_{3}=$ benzyl adenine $\left(\mathrm{BA} 30 \mathrm{ppm}, 30 \pm 2^{\circ} \mathrm{C}\right.$ ), $\mathrm{T}_{4}=$ gibberellic acid $\left(\mathrm{GA}_{3} 150 \mathrm{ppm}, 30 \pm 2^{\circ} \mathrm{C}\right), \mathrm{T}_{5}=$ benzyl adenine $\left(\mathrm{BA} 30 \mathrm{ppm}, 15^{\circ} \mathrm{C}\right) \mathrm{T}_{6}=$ gibberellic acid $\left(\mathrm{GA}_{3} 150 \mathrm{ppm}, 15^{\circ} \mathrm{C}\right), \mathrm{SE}=$ standard error 


\subsection{Total soluble solids (TSS)}

Varietal difference in terms of total soluble solids content was significant at different days of storage. The variety $\mathrm{V}_{1}$ had the higher TSS content $(24.39 \%)$ at the $9^{\text {th }}$ day of storage and TSS value for $\mathrm{V}_{2}$ was lower (17.47\%) (Table 2). The highest TSS $(26.86 \%)$ was recorded in $\mathrm{T}_{0}$ while the least TSS $(16.12 \%)$ was recorded in $\mathrm{T}_{6}$ at the $9^{\text {th }}$ day of storage (Table 3 ) but after the $9^{\text {th }}$ day the TSS content decreased. The highest TSS $(28.35 \%)$ was observed in $\mathrm{V}_{1} \mathrm{~T}_{0}$ while the lowest $(11.65 \%)$ was recorded in $\mathrm{V}_{2} \mathrm{~T}_{6}$ at the $9^{\text {th }}$ day after storage (Table 4). Increasing in the TSS content observed in the present investigation was in partial agreement with the report by Patil and Hulamani (1998) who that $\mathrm{GA}_{3}$ treated fruits had the highest TSS at the end of storage. An increase in the TSS content up to certain period during storage was possibly due to hydrolysis of starch into sugar. Increase in the TSS of banana during ripening was also noticed by Tripathi et al. (1981), Abdullah et al. (1985) and Munasque and Mendoza (1990).

\section{6. pH of banana pulp}

The maximum pulp $\mathrm{pH}$ (6.13) was recorded in $\mathrm{V}_{1}$ and the minimum (5.86) in $\mathrm{V}_{2}$ was at the $9^{\text {th }}$ day of storage (Table 2). $\mathrm{GA}_{3}+15^{\circ} \mathrm{C}$ treated fruit showed comparatively lower $\mathrm{pH}$ value (4.46) at the $9^{\text {th }}$ day of storage. On the other hand, the higher $\mathrm{pH}$ values (6.28) were recorded in $\mathrm{T}_{0}$ and lower (4.46) in $\mathrm{T}_{6}$ at the $9^{\text {th }}$ day of storage (Table 3 ). At the $9^{\text {th }}$ day of storage, $\mathrm{V}_{1} \mathrm{~T}_{0}$ had the highest $\mathrm{pH}$ value (6.79) and the lowest (4.12) was noticed in $\mathrm{V}_{2} \mathrm{~T}_{6}$ (Table 4). The increase in $\mathrm{pH}$ may be due to continuous reduction of acidity during ripening. In the present investigation, increase in $\mathrm{pH}$ was recorded during the storage and this result is in agreement with the findings of Pathak and Sanwal (1999) who observed that $\mathrm{pH}$ of fruit pulp got accelerated when banana fruits were soaked in $0.2 \% \mathrm{GA}_{3}$ solution. The finding of the present investigation was also similar with these of Kumar and Singh (1993) who observed that the pulp $\mathrm{pH}$ of mango increased during its storage.

\subsection{Shelf life}

Highly significant variations were obtained for the shelf life of two varieties of banana. The shelf life of $\mathrm{V}_{2}$ (14.56 days) was higher than that of $V_{1}$ (10.25 days) (Fig. 9). The maximum shelf life (14.97 days) was observed in $\mathrm{T}_{6}$ whereas the minimum (8.20 days) was in $\mathrm{T}_{0}$ (Fig. 10). Pinaki et al. (1997) reported that the matured and fully developed banana fruits of uniform size dipping into $\mathrm{GA}_{3}(150 \mathrm{ppm})$ was most effective for prolonging the shelf life of banana. The treatment $\mathrm{GA}_{3}$ causes the decrease in the tissue permeability and thereby reduced the rate of water loss leading to delayed fruit ripening (Nirupama et al., 2010). This finding is also in agreement with those of Ranwala and Miller (2000) and Singh et al. (2008). The maximum shelf life (16.25 days) was found in $\mathrm{V}_{2} \mathrm{~T}_{6}$ and the minimum (6.78 days) was recorded in $\mathrm{V}_{1} \mathrm{~T}_{0}$ (Fig. 11).

\section{Conclusions}

The chemical properties of banana were greatly influenced by different kinds of postharvest treatments and varieties. The findings indicated that the total soluble solids, sugars (reducing, non-reducing and total sugar) and pulp $\mathrm{pH}$ of fruits increased during the storage treatments. The increasing trend was slower both in $\mathrm{GA}_{3}+$ $15^{\circ} \mathrm{C}$ and $\mathrm{BA}+15^{\circ} \mathrm{C}$ treated bananas. At the same time titratable acidity decreased but that was not rapid in fruits treated with $\mathrm{GA}_{3}$ kept at $15^{\circ} \mathrm{C}$. Among the treatments, $\mathrm{GA}_{3}+15^{\circ} \mathrm{C}$ appeared to be more suitable for extending the shelf life as well as other desirable quality attributes of harvested banana fruits.

\section{References}

Abdullha, H. M. A., Rohaya, M. A. and Zaipun, M. Z. 1985. Physicochemcial changes during maturation and after ripening of bananas (Musa sapientum cv. Embun). MARDI Research Bulletin, 13(3): 341347. 
Afshar, M. M., and Rahim, J. 2010. The comparison of carbohydrate and mineral changes in three cultivars of kiwi fruit of northern Iran during fruit development. Australian Journal of Crop Science, 4:4954.

Akinyemi, S. O. S., Staver, C., Ayelaagbe, I. O. O., Kintomo, A. A. and Babalola, S. O. 2010. Perspectives of small scale Musa processing firms in Nigeria. Acta Horticulture, 879: 287-263.

BBS. 2010. Statistical Yearbook of Bangladesh, Bureau of statistics, Ministry of planning, Government of the People's Republic of Bangladesh, Dhaka.

Bhadra, S. and Sen, S. K. 1999. Postharvest storage of custrard apple (Annona squamosa L.) fruit var. Local Green under various chemical and wrapping treatments. Environmental Ecology. 17(3): 710-713.

Bhattarai D. R., and Gautam, D. M. 2006. Effect of harvesting method and calcium on post harvest physiology of Tomato. Nepal Agricultural Research Journal, 7:37-41.

Bridge John. 2000. Nematodes of bananas and plantains in Africa: Research trends and management strategies relating to the small scale farmer. Acta Horticulture, 540 pp.

Chahidi B., El-Otmani M., Luro F., Srairi I., and Tijane, M. 2008. Changes of fruit quality traits in 7 clementine selections during maturation. Electronic Journal of Environmental, Agricultural and Food Chemistry, 7:2565-2577.

El-Otmani M., Arpaia, M. L. and Coggins, C. W. 1987. Developmental and topophysical effects on the n-alkanes of Valencia orange fruit epicuticular wax. Journal of Agricultural and Food Chemistry, 35:4246.

FAO. 2011. Food and Agriculture Organization of the United Nations. Statistics web site http://www.fao.org, accessed on 04/10/2013.

Gomez, K .A. and A. A. Gomez. 1984. Statistical procedures for agricultural research. John Wiley and Sons. Inc., New York. 67-256 pp.

Holcroft D. M., and Kader, A.A. 1999. Controlled atmosphere induced changes in $\mathrm{pH}$ and organic acid metabolism may affect color of stored strawberry fruits. Postharvest Biology and Technology, 17:19-32

Huber D. J. and O'Donoghue, E. M.. 1993. Polyuronides in avocado (Persea americana) and tomato (Lycopersicon esculentum) fruits exhibit markedly different patterns of molecular weight downshifts during ripening. Plant Physiology, 102:473-480.

Islam, M. S. 1998. Storage life and quality of banana as affected by packaging and coating materials. M.S. thesis, Institute of Postgraduate Studies in Agriculture, Salna, Gazipur, Bangladesh.

Jayaraman, J. 1981. Laboratory Manual in Biochemistry, Wiley Eastern Ltd., New Delhi, India. 122-123.

Kelebek H., Canbas A., and Selli, S. 2008 Determination of phenolic composition and antioxidant capacity of blood orange juices obtained from cvs. Moro and Sanguinello (Citrus sinensis, Osbeck) grown in Turkey. Food Chemistry, 107:1710-1716.

Kulkarni A. P., and Aradhya S. M. 2005. Chemical changes and antioxidant activity in pomegranate seed coats during fruit development. Food Chemistry, 93:319324.

Kumar, P. and Singh, S. 1993. Effect of $\mathrm{GA}_{3}$ and ethrel on ripening and quality of mango cv. Amrapali. Journal of Horticulture, 6(1): 19-23. 
Lu R. 2004. Multispectral imaging for predicting firmness and soluble solid contents of apple fruit. Postharvest Biology and Technology, 31:147-157.

Manasque, V. S. and D. B. Mendoza. 1990. Developmental physiology and ripening behaviour of 'senartia' banana (Musa spp. L) fruits. ASEAN Food Journal, Philippines, 5(4): 152-157.

Miller. 1972. Experiments in molecular genetics. Cold Spring Harbor Laboratory, Cold Spring Harbor, N.Y.

Mondal M. F., Rahman, M. A. and Pramanik, M. A. J. 1995. Effect of different postharvest treatments on physico-chemical changes and shelf life of mango, Bangladesh Horticulture, 23(1\&2):1-5.

Nirupama P. Neeta B. G. and T. V. Ramana Rao .2010. Effect of post harvest treatments on physiochemical Characteristics and shelf life tomato fruits during storage. American-Eurasian Journal of Agriculture \& Environmental Science, 9(5): 470-479.

Pathak, N. and Sanwal, G. G. 1999. Regulation of ripening of banana fruits by chemicals. Indian Journal of Agricultural Science, 69(1): 17-20.

Patil, D. L. and Magar, N. G. 1976. Physicochemical changes in banana fruit during ripening. Journal of Maharashtra Agricultural University, 1: 95-99.

Patil, S. N. and Hulamani, N. C. 1998. Effect of post harvest treatments on physical characters and shelf life of banana fruits. Karnataka Journal of Agricultural Sciences, 11(2): 535-537.

Pinaki, A. K., Rajput, C. B. S., Acharya, P. and Kumar, D.1997. Effect of gibberellic acid, calcium chloride and bavistin on the postharvest life of banana fruits (Musa paradisica L) cv. Dwarf Cavendish. Recent Horticulture, 4: 30-31.
Ranganna, S. 1979. Manual of analysis of fruit and vegetable products. Tata McGraw. Hill Publishing Company Limited, New Delhi. 112 p.

Rangavalli, K., Ravisankar, C. and Prasad, P. H. 1993. Post harvest changes in mango (Mangifera indica L.) var. Banesham. South Indian Horticulture, 41(3): 169-70.

Ranwala, A. P. and Miller, W. B., 2000. Preventing mechanism of gibberellins $4+7$ and light on low-temperature-induced leaf senescence in Lilium cv. stargazer. Postharvest Biology and Technology, 19: 85-92.

Reis, C. M. F., Boas., E. Ude. B. V., Boari, C. A. and Piccoli, R. H. 2004. Quality and shelf life of fresh cut banana "Prata". Ciencia e-Agrotecnologia, 28(3): 696-702.

Siddiqui A. B. and Scanlan, F. M. 1995. Nutritives values of fruits, In: Fruit Production Manual, Hort. Res. Div. Project. (FAO/UNDP/ADB Project: BGD/87/025), 1-286 pp.

Singh, A., Kumarand, J. and Kumar, P. 2008. Effects of plant growth regulators and sucrose on post harvest physiology, membrane stability and vase life of cut spikes of gladiolus. Journal of Plant Growth Regulator, 51: 221-229.

Tripathi, V. K., Ram, H. B., Jain, S. P. and Sing, S. 1981. Changes in development banana fruits. Progressive Horticulture, 13(1): 45-53.

Zhang W., Li X., Zheng J., Wang G., Sun C., Ferguson I., and K. Chen. 2008. Bioactive components and antioxidant capacity of Chinese bayberry (Myrica rubra Sieb. and Zucc.) fruit in relation to fruit maturity and postharvest storage. European Food Research and Technology, 227:10911097. 